\title{
EDITORIAL
}

\section{In This Issue: Longitudinal Follow-up Yields New Insights}

\author{
Kurt C. Stange, $M D, P b D$, Editor \\ Ann Fam Med 2010;8:386. doi:10.1370/1177.
}

$\mathrm{T}$ he articles in this issue show that carefully following people over time can generate understanding that is not available from information analyzed at only one time point. Such longitudinal studies can be challenging to carry out without strong health care system support for continuity of relationships and information, or without considerable investment in individual study cohorts.

The longitudinal studies in this issue reveal:

- Sustainability in improvement from a low-intensity disease management intervention for chronically depressed primary care patients ${ }^{1}$

- The effect of participatory decision making on clinical outcomes in people with diabetes ${ }^{2}$

- The processes by which communication among primary care practice members can be sustained ${ }^{3}$

- How using two different measures of socioeconomic status can reduce potential biases that result in undertreatment of cardiovascular risk factors ${ }^{4}$

- How limited adherence to sequential screening limits the potential effectiveness of fecal occult blood testing for colorectal cancer ${ }^{5}$

- The effect on prescribing patterns of a policy prohibiting pharmaceutical industry interaction and drug samples ${ }^{6}$

- Quality of care of comorbid conditions among long-term cancer survivors in an integrated, population focused, health care system based on primary care ${ }^{7}$

- How a clinician's personal experience of a methacillin-resistant staphylococcus infection can create barriers in relationships with patients ${ }^{8}$

Also in this issue, a qualitative study uses game theory to inform understanding of the relationship between continuity of care and the development of patient trust. ${ }^{9}$

An important study by Williams et $\mathrm{al}^{10}$ shows that from the perspective of community members, current research participant protection criteria do not match the nature of community-based health research.
Finally, a new and potentially helpful way of conceptualizing chronic disease management and behavior change is proposed by Ferrer and Carrasco ${ }^{11}$ and featured in the Annals Journal Club.

Please join the online discussion of these articles at http://www.AnnFamMed.org.

To read or post commentaries in response to this article, see it online at http://www.annfammed.org/cgi/content/full/8/5/386.

\section{References}

1. Klinkman MS, Bauroth S, Fedewa S, et al. Long-term clinical outcomes of care management for chronically depressed primary care patients: a report from the Depression in Primary Care project. Ann Fam Med. 2010;8(5):387-396.

2. Parchman ML, Zeber JE, Palmer RF. Participatory decision making, patient activation, medication adherence, and intermediate clinical outcomes in type 2 diabetes: a STARNet study. Ann Fam Med. 2010;8(5):410-417.

3. Balasubramanian BA, Chase SM, Nutting PA, et al. Using learning teams for reflective adaptation (ULTRA): insights from a teambased change management strategy in primary care. Ann Fam Med. 2010;8(5):425-432.

4. Franks $P$, Tancredi DJ, Winters P, Fiscella K. Including socioeconomic status in coronary heart disease risk estimation. Ann Fam Med. 2010;8(5):447-453.

5. Fenton JJ, Elmore JG, Buist DSM, Reid RJ, Tancredi DJ, Baldwin LM. Longitudinal adherence with fecal occult blood test screening in community practice. Ann Fam Med. 2010;8(5):397-401.

6. Hartung DM, Evans D, Haxby DG, Kraemer DF, Andeen G, Fagnan LJ. Effect of drug sample removal on prescribing in a family practice clinic. Ann Fam Med. 2010;8(5):402-409.

7. Khan NF, Mant D, Rose PW. Quality of care for chronic diseases in a British cohort of long-term cancer survivors. Ann Fam Med. 2010;8(5):418-424.

8. Hass LR. Losing touch in the era of superbugs? Ann Fam Med. 2010;8(5):461-463.

9. Tarrant C, Dixon-Woods M, Colman AM, Stokes T. Continuity and trust in primary care: a qualitative study informed by game theory. Ann Fam Med. 2010;8(5):440-446.

10. Williams RL, Willging CE, Quintero G, Kalishman S, Sussman AL, Freeman WL. Ethics of health research in communities: perspectives from the southwestern United States. Ann Fam Med. 2010;8(5):433-439.

11. Ferrer RL, Carrasco AV. Capability and clinical success. Ann Fam Med. 2010;8(5):454-460. 